\title{
STX7 wt Allele
}

National Cancer Institute

\section{Source}

National Cancer Institute. STX7 wt Allele. NCI Thesaurus. Code C162436.

Human STX7 wild-type allele is located in the vicinity of $6 q 23.2$ and is approximately $67 \mathrm{~kb}$ in length. This allele, which encodes syntaxin-7 protein, is involved in the trafficking of endocytic vesicles. A fusion involving this gene and the ICAM2 gene may be associated with acute monoblastic and monocytic leukemia. 